\title{
Residential Satisfaction in a Mining-Induced Displacement and Resettlement in Ghana
}

\author{
Jackson G. K. Abankwa $^{1 *} \quad$ Ninnette Quaofio $^{1} \quad$ Ibn K. Abdul-Hamid ${ }^{2} \quad$ Yaw Kuffour Sarbeng $^{1}$ \\ 1.School of Architecture and Design, Central University, P. O. Box 2305, Tema, Ghana \\ 2.Department of Marketing, University of Professional Studies, Accra, Ghana
}

\section{Declarations of interest: None}

Funding: This study received no specific grant from any funding agency in the public, commercial, or notfor-profit sectors.

\begin{abstract}
Housing challenges associated with Mining-Induced Displacement and Resettlement have not been examined in literature as much as relocations due to physical development projects like the construction of dams. This study, therefore, endeavours to fill this gap by contributing to discussions on displacements and resettlements communities due to mining activities from the perspective of residential satisfaction. A questionnaire survey was administered to 229 household-heads at Salman, a rural community in the Ellembelle District of the Western Region in Ghana, to investigate the determinants of residential satisfaction in a Mining-Induced Displacement and Resettlement. Residents' assessed their satisfaction based on the physical features of the dwelling units, community facilities, social/neighbourhood environment, and infrastructural services. Data were analysed using mathematical equations to attain residential satisfaction and habitability indices. The study revealed moderate residential satisfaction with the overall resettlement housing. Satisfaction with physical features of the dwelling units was high, while satisfaction with community facilitates and social/neighbourhood environment was moderate. The satisfaction level with infrastructure services was, however, shallow. The study avers that there exist opportunities for real residential satisfaction after permanent mining-induced relocation of communities.

Keywords: Residential satisfaction, Mining-Induced Displacement and Resettlement, Dwelling units, Community facilities, Neighbourhood.
\end{abstract}

DOI: $10.7176 / \mathrm{CER} / 12-9-05$

Publication date:September $30^{\text {th }} 2020$

\section{Introduction}

Development projects, such as urban renewal, natural resource extraction or mining and infrastructure projects usually trigger the displacement of communities and such dislocations worldwide result in the resettlement of about ten million people annually (Downing, 2002; Cernea, 2004; Owen \& Kemp, 2015, 2016). Thus, development-induced displacements and relocations continue to be a significant issue. However, housing issues in Mining-Induced Displacements and Resettlements (MIDR) have not attained as much attention in scholarly literature as those related to physical development projects, such as the construction of dams (Asthana, 1996; Cernea \& McDowell, 2000; Stanley, 2004). Specifically, there is a scarcity of current research on residential satisfaction in MIDR from the residents' perspective, even though community displacements and resettlements caused by natural resource extraction projects are always associated with housing challenges ( $\mathrm{Li} \& \mathrm{Wu}, 2013$; Sonter, Barrett, Soares-Filho \& Moran, 2014).

In Africa, for example, few researchers have explored MIDR (Mkuzi, Mwaguni \& Danda, 2013; Schueler, Kuemmerle \& Schroder, 2011). Similarly, research on resettlements in Ghana has focused more on statedeveloped relocations caused by the construction of dams than on mining-induced resettlements developed by the private sector (Mettle, 2011). As stated by Mettle (2011) and Obour, Owusu, Agyeman, Ahenkan, and Madrid (2016), these resettlement studies emphasised on issues relating to planning, implementation processes, livelihood sustainability, compensation packages and the management of social impacts. The few studies on residential satisfaction in Ghana focussed on urban housing (Baiden, Arku, Luginaah \& Asiedu, 2011), disaster-induced resettlements (Danquah, Attippoe \& Ankrah, 2014), and low-income multi-habitation in metropolitan areas (Addo, 2016).

Therefore, to enhance policies and practices in MIDR programmes, there is the need to investigate residential satisfaction in MIDR, which is a risk to the resettlement of mining-affected people. This study contributes to the existing literature on MIDR by examining the level of residential satisfaction of the Salman MIDR housing scheme, eight years after the permanent relocation of the inhabitants. The objective of the study was to explore the key factors that influenced residential satisfaction in the Salman resettlement. Besides fulfiling a research need, the outcome of the investigation is essential in shaping strategies for future resettlement housing policies, especially for low-income rural communities in developing countries. 


\section{Overview of Literature}

\subsection{Displacements and Resettlements}

'Resettlement' refers to involuntary permanent relocation by way of the provision of houses and services triggered by disaster or large-scale development projects (Asthana, 1996; De Wet, 2000). Natural resource extraction projects trigger MIDR, which result in the loss of direct control of the vast extent of land previously occupied by the people. Thus, MIDR continues to be a significant issue (Askland, 2018; Owen \& Kemp, 2016; van der Ploeg \& Vanclay, 2018), since they always generate land use, resettlement planning and housing challenges (Sonter et al., 2014).

The success of resettlement schemes, especially for rural communities, depends mainly on the integration of socio-cultural values of the displaced persons in the design of the houses and the township neighbourhoods as a symbolic link and identification with the new sites (Adu-Aryee, 1993). Danquah et al. (2014) supported this assertion by postulating that social and cultural ties with neighbours is critical for resettled people to nurture adaptation with relocations. Related to people and their socio-cultural system's responses to resettlements, Scudder and Colson (1982) proposed that any involuntary permanent relocation must pass through four different stages of relocation to be deemed successful. The four-stage model involves recruitment (formulation of development and resettlement plans), transition (informing affected persons of their future displacement), potential development (occurrence of physical relocation), and handing over or incorporation (resettlement in a new community). The Scudder-Colson model, however, does not expound the consequences of forced resettlements relating to the residential satisfaction of the project-affected populations.

\subsection{Satisfaction Model and Theory}

Contemporary researchers have theorised that satisfaction is the extent to which the performance of a product meets a client's expectations (LaTour \& Peat, 1979; Parker \& Mathews, 2001). Jiang, Klein and Saunders (2012) defined satisfaction as the "effect of a judgment of the difference between what is expected or desired, compared to what is experienced about a product or service" (p. 357). In other words, satisfaction is the relationship between a perceived fulfilment of anticipation. According to Parker and Mathews (2001), this satisfaction construct is traceable to the Discrepancy Theory. The Discrepancy Theory can assist in predicting or explaining satisfaction but has limitations to its application (Klein, Jiang \& Cheney, 2009). For this reason, the Discrepancy Model is scarcely used in measuring the magnitude of satisfaction (Jiang et al., 2012) and this has led to the use of other satisfaction models, such as the Contrast Theory and the Expectancy-Disconfirmation model (Jaafar \& Hasan 2005).

The Contrast Theory posits that consumers overstate the contrast between their expectations of a product and the product assessment (Howard \& Sheth, 1969: cited in Parker \& Mathews, 2001). The ExpectancyDisconfirmation Model, on the other hand, hypothesises satisfaction as a functional relationship between consumers' expectations and the obtained performance of a product or service. Clients are positively disconfirmed or satisfied when the performance of a product or service meets or exceeds their expectations. Conversely, they are negatively disconfirmed or dissatisfied when the actual performance is less than their perceived expectations (LaTour \& Peat 1979; Oliver, 1981: cited in Jaafar \& Hasan 2005). Because of inconsistencies in the various satisfaction paradigms, satisfaction indices, such as the American Consumer Satisfaction Index (ACSI) and the European Customer Satisfaction Index (ECSI), have been developed to harmonise customer satisfaction in the respective nations (Jaafar \& Hasan 2005). Notwithstanding, Al-Eisa and Alhemoud (2009) contended that an individual's satisfaction could be assessed based on specific contextualised determinants.

\subsection{Residential Satisfaction}

Various authors (Galster, 1985, 1987; Mohit, Ibrahim \& Rashid, 2010; Morris \& Winter, 1975, 1978) have postulated different theoretical and conceptual frameworks to explain the concept of residential satisfaction. Residential satisfaction, defined as the fulfilment one has in a house or housing environment, is based on one's requirements, expectations, goals and or accomplishments (Hui \& Yu, 2009; Jiboye, 2012; Mohit et al., 2010). Galster (1987), Hashim, (2003), Ibem and Aduwo (2013), also described residential satisfaction as the degree of the occupants' gratification with their housing units and the social environment. According to Djebuarni and AlAbed (2000) and Mohit et al., (2010) residential satisfaction is a significant predictor of one's discernment of overall quality of life and an indicator of residents' perception of the quality of their housing environment. Residential satisfaction is, therefore, a tool for measuring the success or failure of housing projects and the extent of residential mobility and neighbourhood change (Amerigo \& Aragones, 1997).

Morris and Winter $(1975,1978)$ introduced the 'housing deficit' model to explain residential satisfaction and mobility practices. They opined that households assess their housing conditions according to their personal and cultural norms, which may be independent of each other. Thus, residential satisfaction depends on the level of congruity between the housing conditions and the individual behavioural and cultural norms, to the extent that inconsistency results in a housing deficit that in turn leads to residential dissatisfaction or vice versa. Housing 
deficits generate housing adjustments, either by improving the housing environment through remodelling or by the relocation of a household to a different housing setting (Morris \& Winter, 1975, 1978).

Another perspective of the residential satisfaction concept is Galster's (1987) two complementary empirical models, namely the purposive approach and the actual-aspiration gap approach. Concerning the purposive approach, Galster (1985) explained residential satisfaction as an indicator of the extent to which one's housing environment is perceived to enable the realisation of one's goals based on the specific aims. Housing, therefore, is regarded as a facilitator for achieving one's aspiration in life, with residential satisfaction being a measure of the notable performance of housing in facilitating the overall achievement of one's goals. Regarding the actualaspiration gap approach, residential satisfaction evaluates the difference between residents' actual housing conditions and the ideal housing and neighbourhood environments they aspire to have (Galster, 1987). However, households' housing needs and aspirations change across the stages of the family life cycle resulting in residential dissatisfaction and subsequently residential mobility or migration with the intent to increasing one's level of residential satisfaction (Mohit et al., 2010).

The underpinnings of the reviewed concepts suggest that residents' assessment of their residential satisfaction largely depends on three factors, namely, their preferences, their aspirations and their needs. These elements reflect the conceived ideal housing environments they desire to facilitate the achievement of their goals. Thus, many empirical global studies measured residential satisfaction using various variables representing dwelling units, municipal facilities, infrastructural services and neighbourhood environment (Baiden, Arku, Luginaah. \& Asiedu, 2011; Ibem \& Aduwo, 2013; Lane \& Kinsey, 1980; Lu, 1999; Mohit et al., 2010; Rohe, Zandt \& McCarthy, 2013; Salleh, 2008; Sinai, 2001). The effects of these fundamental variables as factors of residential satisfaction or dissatisfaction are inclined to variation depending on the type of housing, home-ownership or tenancy, location or context, and culture (Andersen, 2008; Lu, 1999).

For instance, Lane and Kinsey (1980) concluded from a study on residential satisfaction in the United States that housing features influenced residents' satisfaction levels. Savasdisara, Tips and Suwannodom (1989) also opined that occupants in low-cost housing in Bangkok, Thailand, were much more satisfied with the physical structure and appearance of their houses than with the environment and municipal facilities. Similarly, Ha (2008), Ibem and Amole (2013), Ilesanmi (2010), Jiboye (2009) and Salleh (2008) posited that public housing occupants tend to be more satisfied with their housing units than the neighbourhood environments. In contrast, a study conducted in Hong Kong revealed that residents in public housing were somewhat dissatisfied with the building structure, in addition to the environmental cleanliness (Liu, 1999). Mohit et al., (2010) also unveiled from a study on low-income public housing in Kuala Lumpur, Malaysia, that while the residents were delighted with the housing support services, they were moderately satisfied with the physical features of their houses and dissatisfied with the neighbourhood environment of the area.

Similarly, Salleh (2008) observed that residents in Penang and Terengganu in Kuala Lumpur, Malaysia, rated their satisfaction levels high with features of the housing units and services. Still, they were disappointed with their neighbourhoods because of insecurity, lack of recreation and civic amenities, and infrastructure for people with disabilities. Residents of public housing estates in South Korea also expressed profound dissatisfaction with their neighbourhood environment due to inadequate parking facilities and poor landscaping (Ha, 2008). Parke, Kearns and Atkinson (2002), on the other hand, observed from a survey on housing in the United Kingdom that housing neighbourhoods relating to appearance, noise levels, security, and community friendliness, were a significant fundamental factor of high residential satisfaction. In the less affluent neighbourhoods, crime and unfriendliness negatively affected residential satisfaction while owner-occupiers were dissatisfied with the locality where their share of occupancy was relatively low.

Elsewhere in Africa, Ogu (2002) concluded from a study on urban housing in Benin City, Nigeria, that variables relating to the features of the houses influenced residential satisfaction positively as against environmental factors. In the same way, results from studies by Ilesanmi (2010), Jiboye (2009), Olatubara and Fatoye (2007) on public housing in Lagos, Nigeria, indicated that the physical features and spatial configurations of the housing units were the significant determining parameters of residents' high level of satisfaction. They were dissatisfied with the management and maintenance of facilities and the overall planning of the townships, including proximity to community facilities. In another study on public housing in Ogun State, Nigeria, Ibem and Aduwo (2013) concluded that the residents were generally not satisfied with the overall conditions of the neighbourhood environment. Their level of satisfaction was, however, much higher for the dwelling units than community facilities and the neighbourhood milieu. However, in Abuja, Nigeria, the residential satisfaction among occupants of public housing was much higher with community facilities, especially regarding proximity to such facilities, than the physical features and spatial arrangements of the dwellings, management and maintenance of facilities (Ukoha \& Beamish, 1997).

In Ghana, Baiden et al. (2011) revealed that the physical characteristics of houses were vital factors that influenced residential satisfaction in three different neighbourhoods in Accra, the capital city. Research on residential satisfaction among residents of three disaster-induced resettlement townships in the Keta Basin revealed 
that the inhabitants were satisfied with the housing units and infrastructure services, which were perceived to be considerably better than those in their original communities, were. They were, however, not contented with the sizes and number of bedrooms and the sizes of land allotted to each household (Danquah et al., 2014). Addo (2016), on the other hand, established that housing features negatively affected residential satisfaction of multihabited low-income households. Still, community services and neighbourhood characteristics exhibited high positive and moderate satisfaction impacts, respectively.

In summary, it is evident from the preceding reviewed literature that residential satisfaction is a complex construct that is influenced by factors that are directly related to housing features and the environs. Most of the reviewed research, therefore, dealt with the measurement of residential satisfaction through an objective approach. This approach examined respondents' appraisal of the objective attributes of housing relating to the physical characteristics of the dwelling units, community facilities, neighbourhood and social environment and infrastructure services. The effect of the determinants of residential satisfaction, however, differ by the type of housing, countries of locations, residents' culture, tenures and or modes of acquisition, as propounded by Theodori (2001) and Ogu (2002). Thus, from the perspective of the relocated Salman residents, this study measured the residential satisfaction, as a composite of the characteristics of the houses, the community facilities, the neighbourhood environment and infrastructure services. The study attempts to fill a knowledge gap in assessing the feelings of residents of MIDR about their residential settings.

\subsection{Study Setting, Materials and Methods}

\subsection{Study Setting}

The study explored a practical example of a MIDR in the new Salman town located in the Ellembelle District of Western Region in Ghana, as shown in Figure 1. The resettlement was commissioned in 2012 to relocate 2,154 people displaced because of commercial extraction of gold ore near the old Salman town depicted in Figure 2. A thirty-member resettlement negotiation and implementation committee, comprising representatives of the projectaffected persons, statutory agencies and the private mining company, was constituted to negotiate the resettlement package. The output of the committee's consultations was a resettlement action plan that became the blueprint for the implementation of the project.

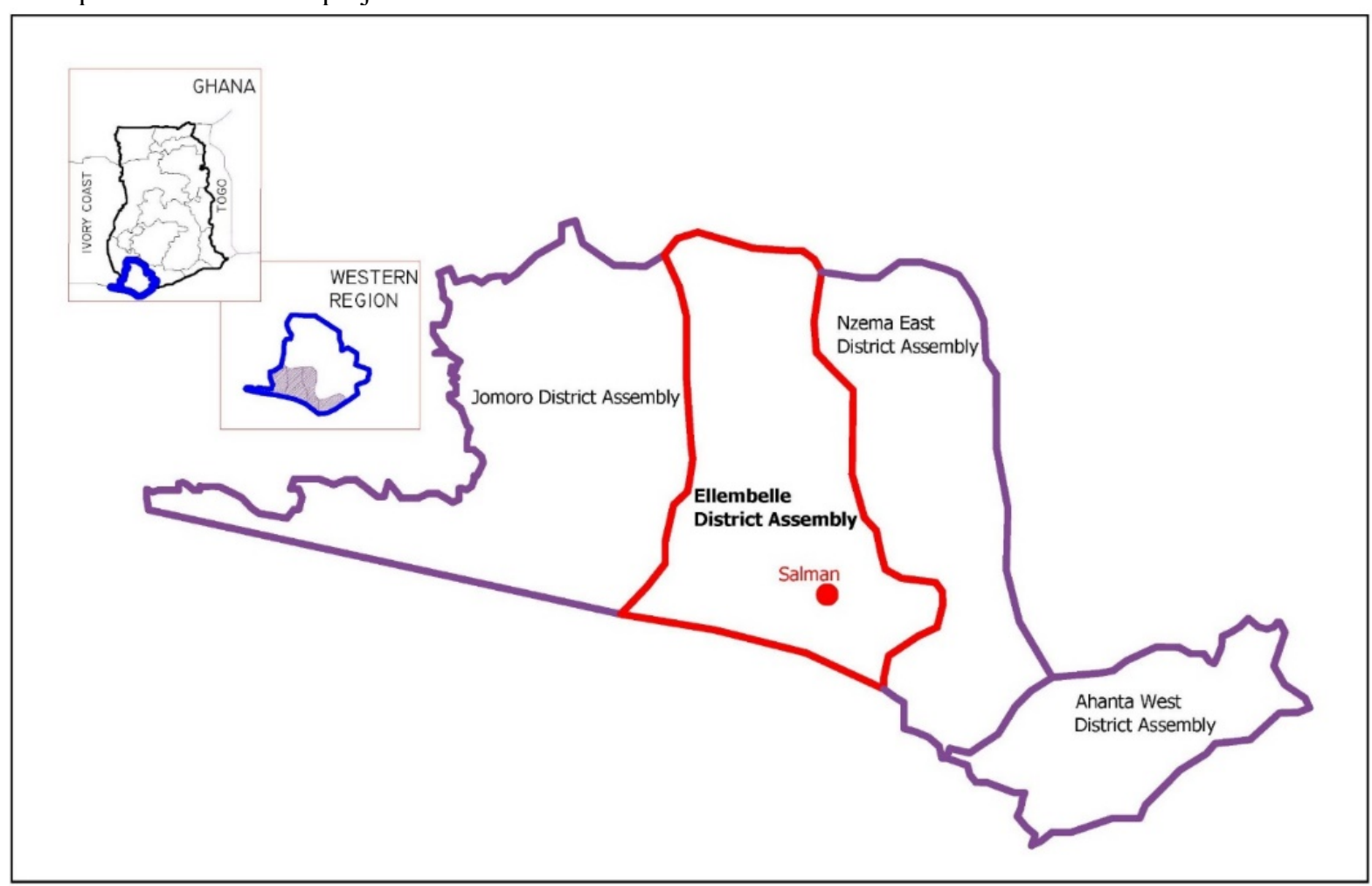

Figure 1: Location of the New Salman Town (Source: Authors' construct) 

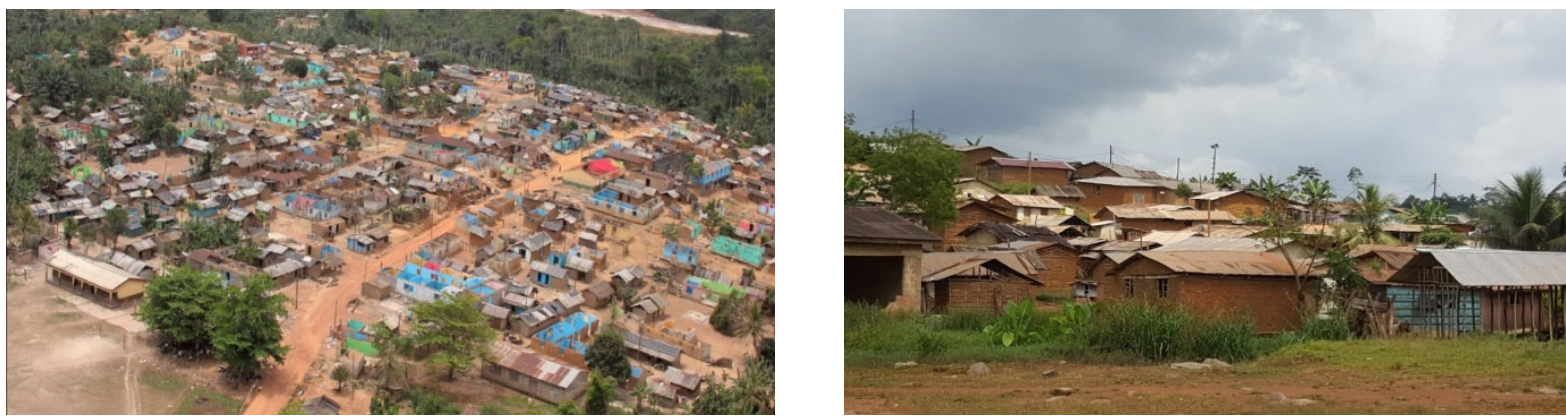

Figure 2: The old Salman Town (Source: Ellembelle District Assembly)

The physical layout of the resettlement, which involved the spatial planning of a 101.17-hectare land located about 1.5 kilometres east of the old Salman town, is illustrated in Figure 3. The basis of the replacement of the buildings was "room for a room" or "structure for structure". For example, a house with one room was replaced with a one-room structure, and an owner of a house with two-rooms had a two-room apartment as a replacement. The new homes had standardised room sizes of $3.66 \mathrm{~m} \mathrm{x} 3.66 \mathrm{~m}$ for all existing rooms that were $3.66 \mathrm{~m} \mathrm{x} 3.66 \mathrm{~m}$ or less, whereas old apartments, which were larger than $3.66 \mathrm{~m} \times 3.66 \mathrm{~m}$, were substituted with standardised sizes of $3.66 \mathrm{~m} \times 4.57 \mathrm{~m}$. The dimensions of the land allocated for each house ranged from $3.66 \mathrm{~m} \times 3.66 \mathrm{~m}$ to $21.34 \mathrm{~m} \times$ $30.48 \mathrm{~m}$, depending on the number of rooms in the old house.

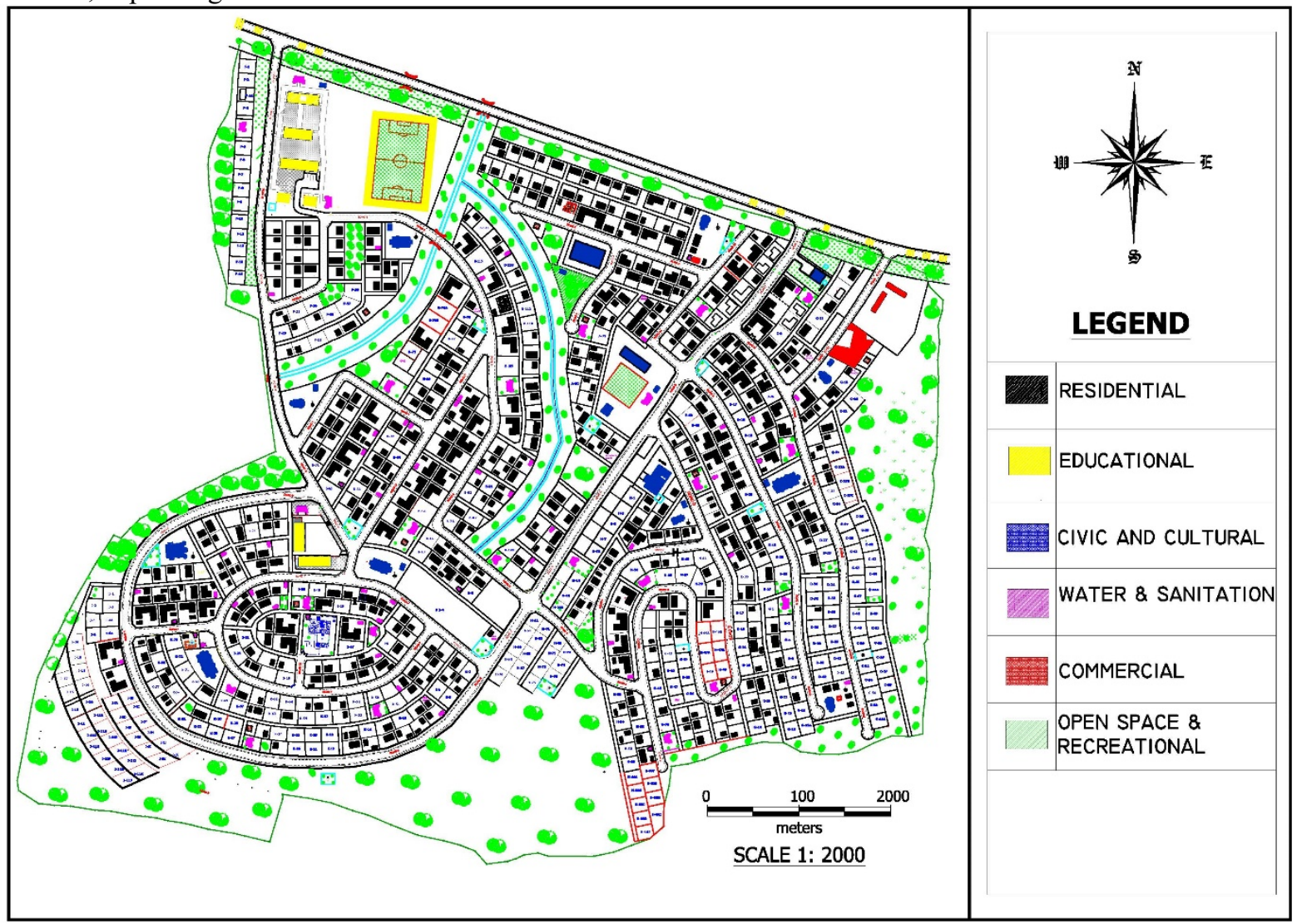

Figure 3: Layout of the New Salman Town (Source: Ellembelle District Assembly)

In addition to the replacement of 724 residential dwellings, other structures and infrastructure built to replace existing facilities included three schools, two churches and a mosque, 18 public toilets, electricity, streets and boreholes. The private developer also constructed additional facilities, which did not exist in the old village. These included a marketplace, a community centre, a palace for the chief of the town, a clinic and a police station with staff quarters, landscaping, refuse collection pads, stormwater drains and street lights. Figure 4 shows street views and standard dwelling units in the new Salman town. 

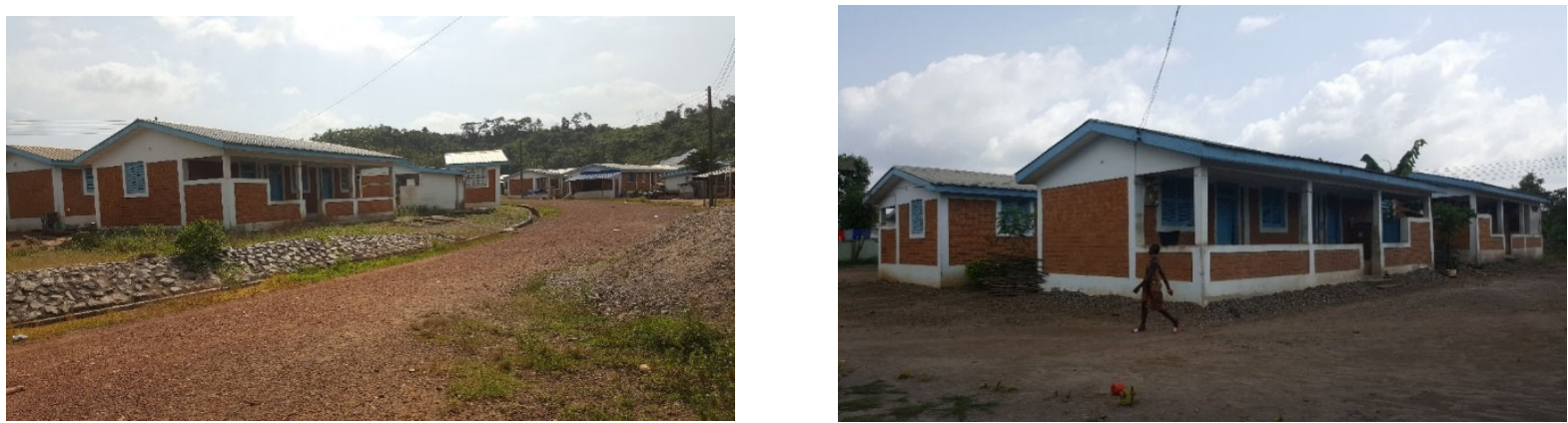

Figure 4: The new Salman Town (Source: Authors' Field Survey, 2020)

\subsection{Material and Methods}

Direct household survey data were collected in Salman with the complement of informal interviews. A sample of 258 houses $(\mathrm{n}=258)$ was generated from 724 housing units $(\mathrm{N}=724)$, based on the formula, $\mathrm{n}=\mathrm{N} / 1+\mathrm{N}\left(\mathrm{e}^{2}\right)$ (Yamane, 1967: cited in Singh \& Masuku, 2014), with a confidence level of 95\%, and a margin of error of 5\%. At the end of the survey, 229 valid questionnaires, representing $88.76 \%$, were obtained and used for the analysis.

As recommended by Fowler (1993), structured questionnaire, containing mostly 'closed' questions and a few 'open-ended' ones, was used to gather data because the population was within the low-income and low-education brackets and was located in a rural area. For each house, the head of the household, or in his absence an adult, was selected as the respondent for the survey. The questionnaire consisted of 28 satisfaction variables comprising the physical attributes of residential units ( 8 items), community facilities ( 8 items), social and neighbourhood environment (6 items) and infrastructure services (6 items).

Data were obtained using a five-point Likert-type scale ranging from (1) for 'Very Dissatisfied', (2) for 'Dissatisfied', (3) for 'Neutral', (4) for 'Satisfied', and (5) for 'Very Satisfied'. The respondents' tallies for each variable were summed up for the computation of the satisfaction indices. By dividing the summation of the scores generated from the Likert scale by the potential maximum full score and multiplying the result by 100 , the respondent's percentage satisfaction index was obtained (Addo, 2016; Ogu, 2002). The following formula (Ogu, 2002; Mohit et al., 2010) was used to calculate the satisfaction index for the components of residential satisfaction:

$$
S I c=\frac{\sum_{i}^{N}=1 y^{i}}{\sum_{i}^{N}=1 Y^{i}} \times 100
$$

Where SI is a respondent's satisfaction index in respect of factor $\mathrm{c}$ of the housing environs; $\mathrm{c}$ is a component of the residential environment; $\mathrm{N}$ is the total of variables grouped under factor $\mathrm{c}$; $\mathrm{yi}$ is the respondent's score on the ith variable, and $\mathrm{Yi}$ is the highest possible tally that $\mathrm{i}$ could earn on the scale used. The satisfaction indices were subsequently calculated for the dwelling units, the community facilities and the neighbourhood environment and divided into the following quartiles of satisfaction levels: very low (0-25\%), low (25.1-50\%), moderate (50.1$75 \%)$ and high (75.1-100\%).

Similarly, the residential satisfaction index was derived as the summation of the component satisfaction indices. To determine the specific variables that contribute to the extent of the respondents' residential satisfaction, or otherwise, Habitability Index (Ogu, 2002; Mohit et al., 2010) was computed using the mathematical expression below:

$$
H I x=\frac{\sum_{i=1}^{N} a y^{\prime} x}{\sum_{i=1}^{N} A y^{\prime} x} \times 100
$$

Where "HIx is the Habitability Index of $\mathrm{x}$ variable and $\mathrm{N}$ represents the sample size while ay' $\mathrm{x}$ is the actual score on the five-point by the yth respondent on the xth variable. 'A' represents the maximum possible score that respondent $y$ ' could give to variable $x$ on the five-point scale" (Mohit et al., 2010, p. 22).

\section{Findings and Discussions}

As shown in Table 1, the majority of respondents (69.43\%) were males (male-headed households), and females (female-headed families) accounted for $30.57 \%$ of the population. The highest proportion of the respondents $(42.35 \%)$ were within the age range of 41-50, while the age range of 51-60 recorded the second-highest frequency of $25.33 \%$. The household size of 5-6 members constituted $37.12 \%$, followed by the household size of 3-4, representing $33.19 \%$. About $44.54 \%$ of the respondents had monthly incomes of less than GH500.00 ( $\$ 100.00)$, and $40.17 \%$ of respondents had no education, but $25.33 \%$ of them had attained primary education. Most of the respondents $(85.15 \%)$ had lived in the new township since its relocation in 2012, and $58.52 \%$ of them owned the houses they lived in, while $25.76 \%$ of respondents lived in inherited houses. 
Table 1: Socio-demographic Features of Respondents

\begin{tabular}{|c|c|c|c|}
\hline \multicolumn{2}{|c|}{ Socio-demographic characteristics of Respondents } & Frequency & Percentage \\
\hline \multirow{3}{*}{ Gender } & Male & 159 & 69.43 \\
\hline & Female & 70 & 30.57 \\
\hline & Total & 229 & 100 \\
\hline \multirow{6}{*}{ Age Range } & $21-30$ & 7 & 3.06 \\
\hline & $31-40$ & 34 & 14.85 \\
\hline & $41-50$ & 97 & 42.35 \\
\hline & $51-60$ & 58 & 25.33 \\
\hline & Above 60 & 33 & 14.41 \\
\hline & Total & 229 & 100 \\
\hline \multirow{5}{*}{ Size of Household } & $1-2$ & 24 & 10.48 \\
\hline & $3-4$ & 76 & 33.19 \\
\hline & $5-6$ & 85 & 37.12 \\
\hline & Above 6 & 44 & 19.21 \\
\hline & Total & 229 & 100 \\
\hline \multirow{5}{*}{$\begin{array}{l}\text { Monthly Income Levels GHC } \\
\quad(\mathrm{US} \$ 1.00=\text { GHC5.00) }\end{array}$} & $\leq 500$ & 102 & 44.54 \\
\hline & $501-1000$ & 60 & 26.21 \\
\hline & $1001-1500$ & 59 & 25.76 \\
\hline & Above 1,500 & 8 & 3.49 \\
\hline & Total & 229 & 100 \\
\hline \multirow{5}{*}{ Educational Level } & No Education & 92 & 40.17 \\
\hline & Basic Education & 58 & 25.33 \\
\hline & Senior High School & 34 & 14.85 \\
\hline & Tertiary & 45 & 19.65 \\
\hline & Total & 229 & \\
\hline \multirow{4}{*}{ Length of Residency } & Less than a year & 6 & 2.62 \\
\hline & $1-3$ years & 28 & 12.23 \\
\hline & $4-6$ years & 195 & 85.15 \\
\hline & Total & 229 & 100 \\
\hline \multirow{4}{*}{ Tenure status/Property Ownership } & Owner Occupied & 134 & 58.52 \\
\hline & Inherited & 59 & 25.76 \\
\hline & Rented & 36 & 15.72 \\
\hline & Total & 229 & 100 \\
\hline
\end{tabular}

Source: Authors' Fieldwork, 2020

The satisfaction index for each of the 28 attributes and the habitability indices for the corresponding four components (residential satisfaction index) are presented with means and standard deviations in Table 2 . The study established that the residents perceived a moderate level of residential satisfaction (70.43) with their overall housing quality. Out of the four residential components, the habitability index for physical features of dwelling units was highest at $80.33 \%$, followed by a moderate level of $77.85 \%$ for community facilities. Similarly, neighbourhood environment achieved a moderate habitability index of $72.13 \%$, compared with the lowest habitability index of $38.86 \%$ for infrastructure services.

All the attributes of dwelling units had moderate to high habitability indices ranging from 62.45 (the type of construction materials, fittings and fixtures used) to 95.98 (aesthetic appearance of the residences). Similarly, the habitability index for social/neighbourhood environment ranged from a moderate 62.97 (proximity of the home to a place of work) to a high 87.88 (design of township consistent with cultural values). For the community facilities, six of the eight variables attained moderate to high habitability indices ranging from 64.19 (public toilet facilities) to 95.63 (Primary and Junior High Schools). Still, one variable (market/shopping facilities) achieved a low index of 28.03. Whereas the habitability index of one infrastructure services variable was high at 87.08 (road network and pedestrian walkways), it was deficient at 24.37 for garbage/waste collection/disposal systems and 22.45 for management and maintenance of facilities. The results indicate that the respondents' satisfaction is pronounced in the dwelling units, community facilities and neighbourhood environment components while their dissatisfaction is evident in the infrastructural services component. Table 3 shows the rank-ordered habitability indices of all the physical attributes of residential satisfaction in Salman. 
Table 2: Determinants of Residential Satisfaction

\begin{tabular}{|c|c|c|c|c|}
\hline Code & Items & $\begin{array}{l}\text { Habitability } \\
\text { Index }\end{array}$ & Mean & $\begin{array}{l}\text { Standard } \\
\text { Deviation }\end{array}$ \\
\hline FDU & $\begin{array}{l}\text { Satisfaction with Physical Features of Dwelling } \\
\text { Units (8) }\end{array}$ & 80.33 & & \\
\hline FDU6 & The aesthetic appearance of the residences & 95.98 & 4.80 & 0.83 \\
\hline FDU1 & Size of living room spaces & 89.52 & 4.48 & 1.34 \\
\hline FDU8 & $\begin{array}{l}\text { Design of the house with occupant's cultural way } \\
\text { of life }\end{array}$ & 88.30 & 4.41 & 1.33 \\
\hline FDU7 & Natural daylighting and airflow in rooms & 86.38 & 4.32 & 1.45 \\
\hline FDU5 & $\begin{array}{l}\text { Adequacy and efficiency of electrical services and } \\
\text { water supply }\end{array}$ & 78.52 & 3.93 & 1.71 \\
\hline FDU4 & Location of the dwelling unit in the township & 72.05 & 3.60 & 1.90 \\
\hline FDU2 & Size and location of the kitchen & 69.43 & 3.47 & 1.45 \\
\hline FDU3 & $\begin{array}{l}\text { Type of construction materials, fittings and fixtures } \\
\text { used }\end{array}$ & 62.45 & 3.12 & 1.97 \\
\hline SCF & Satisfaction with Community Facilities (8) & 77.85 & & \\
\hline SCF5 & Primary and Junior High Schools & 95.63 & 4.78 & 0.88 \\
\hline SCF6 & Public Medical/Healthcare facility & 95.37 & 4.77 & 0.64 \\
\hline SCF2 & Places of worship/religious buildings & 92.84 & 4.64 & 1.09 \\
\hline SCF8 & $\begin{array}{l}\text { Open spaces for community gatherings and } \\
\text { recreation }\end{array}$ & 88.82 & 4.44 & 1.34 \\
\hline SCF1 & Community Centre & 87.07 & 4.35 & 1.48 \\
\hline SCF4 & Dedicated lorry/bus/taxi station or transit points & 70.83 & 3.54 & 1.85 \\
\hline SCF3 & Public toilet facilities & 64.19 & 3.21 & 1.97 \\
\hline SCF7 & Market/shopping facilities & 28.03 & 1.40 & 1.18 \\
\hline SNE & $\begin{array}{l}\text { Satisfaction with Social/Neighbourhood } \\
\text { Environment (6) }\end{array}$ & 72.13 & & \\
\hline SNE5 & Design of township with cultural values & 87.77 & 4.39 & 1.38 \\
\hline SNE2 & $\begin{array}{l}\text { The proximity of the home to various community } \\
\text { facilities }\end{array}$ & 81.57 & 4.08 & 1.61 \\
\hline SNE1 & The site for the relocation of the new town & 72.40 & 3.62 & 1.87 \\
\hline SNE6 & $\begin{array}{l}\text { Nearness to immediate neighbours in the old } \\
\text { township }\end{array}$ & 64.19 & 3.21 & 1.98 \\
\hline SNE4 & Security of life and property & 63.84 & 3.19 & 1.96 \\
\hline SNE3 & The proximity of the home to a place of work & 62.97 & 3.15 & 1.82 \\
\hline SIS & Satisfaction with Infrastructural Services (6) & 38.86 & & \\
\hline SIS1 & Road network and pedestrian walkways & 87.07 & 4.35 & 1.45 \\
\hline SIS2 & $\begin{array}{l}\text { Quality and availability of potable water } \\
\text { supply/boreholes }\end{array}$ & 62.62 & 3.13 & 1.95 \\
\hline SIS4 & Street lighting & 48.99 & 2.45 & 1.87 \\
\hline SIS5 & Sanitary services/cleanliness of the neighbourhood & 28.38 & 1.42 & 1.12 \\
\hline SIS3 & Garbage/waste collection/disposal systems & 24.37 & 1.22 & 0.82 \\
\hline SIS6 & Management and maintenance of facilities & 22.45 & 1.12 & 0.64 \\
\hline RSI & Overall Residential Satisfaction Index (28) & 70.43 & & \\
\hline
\end{tabular}

Notes - (FDU: Features of Dwelling Units; SCF: Community Facilities; SNE: Social/Neighbourhood Environment; SIS: Infrastructural Services)

Source: Authors' Fieldwork, 2020

The resultant overall moderate residential satisfaction of the residents, which is similar to previous studies (Ibem \& Amole, 2013; Li \& Song, 2009; Mohit et al., 2010; Savasdisara et al., 1989), was facilitated by the positive contributions of dwelling units, community facilities and neighbourhood environment components. The high indices of habitability obtained by the three elements can be attributed to the involvement of the project-affected persons and relevant statutory agencies in the formulation of the resettlement package for the implementation of 
the project, as opined by Shaw and Ahmed (2010).

The high habitability index recorded by the dwelling unit component over the other components is akin to previous findings in Ghana (Baiden et al., 2011; Danquah et al., 2014), Nigeria (Ibem \& Amole, 2013; Ilesanmi, 2010; Jiboye, 2009; Ogu, 2002; Olatubara \& Fatoye, 2007), South Korea (Ha (2008), Michigan, USA (Lane \& Kinsey, 1980), Malaysia (Salleh, 2008) and Thailand (Savasdisara et al., 1989). However, the findings contradict other studies which indicated that residents in public housing were more satisfied with neighbourhood environments than dwelling units characteristics (Ha, 2008; Mohit et al., 2010; Ukoha \& Beamish, 1997). In this study, all the variables in the dwelling unit component made positive contributions to residential satisfaction because residents received better replacements for their houses even though the designs were standardised. The attainment of moderate to high indices by all the attributes of the community facilities and social/neighbourhood environment components, except for the market and shopping facilities, is somewhat inconsistent with some previous residential satisfaction studies (Ibem \& Aduwo, 2013; Mohit et al., 2010; Ogu, 2002; Salleh, 2008; Savasdisara et al., 1989). The residents were pleased with the provision of the community facilities either because such amenities did not exist, or were perceived to be significant improvements of what existed in the old village. The inhabitants were, however, very dissatisfied with the market and shopping facilities because these amenities were remotely located at the periphery of the town.

Table 3: Ranking order of Residential Satisfaction Determinants

\begin{tabular}{|c|c|c|c|}
\hline Components & Description of Variables & $\begin{array}{c}\text { Satisfaction } \\
\text { Indices }\end{array}$ & Rank \\
\hline FDU6 & The aesthetic appearance of the residence & 95.98 & 1 \\
\hline SCF5 & Primary and Junior High Schools & 95.63 & 2 \\
\hline SCF6 & Public Medical/Healthcare facility & 95.37 & 3 \\
\hline SCF2 & Places of worship/religious buildings & 92.84 & 4 \\
\hline FDU1 & Size of living room spaces & 89.52 & 5 \\
\hline SCF8 & Open spaces for community gatherings and recreation & 88.82 & 6 \\
\hline FDU8 & Design of the house with occupant's cultural way of life & 88.30 & 7 \\
\hline SNE5 & Design of township with cultural values & 87.77 & 8 \\
\hline SCF1 & Community Centre & 87.07 & 9 \\
\hline SIS1 & Road network and pedestrian walkways & 87.07 & 10 \\
\hline FDU7 & Natural daylighting and airflow in rooms & 86.38 & 11 \\
\hline SNE2 & The proximity of the home to various community facilities & 81.57 & 12 \\
\hline FDU5 & Adequacy and efficiency of electrical services and water supply & 78.52 & 13 \\
\hline SNE1 & The site for the relocation of the new town & 72.40 & 14 \\
\hline FDU4 & Location of the dwelling unit in the township & 72.05 & 15 \\
\hline SCF4 & Dedicated lorry/bus/taxi station or transit points & 70.83 & 16 \\
\hline FDU2 & Size and location of the kitchen & 69.43 & 17 \\
\hline SCF3 & Public toilet facilities & 64.19 & 18 \\
\hline SNE6 & Nearness to immediate neighbours in the old township & 64.19 & 19 \\
\hline SNE4 & Security of life and property & 63.84 & 20 \\
\hline SNE3 & The proximity of the home to a place of work & 62.97 & 21 \\
\hline SIS2 & Quality and availability of potable water supply/boreholes & 62.62 & 22 \\
\hline FDU3 & Type of construction materials, fittings and fixtures used & 62.45 & 23 \\
\hline SIS4 & Street lighting & 48.99 & 24 \\
\hline SIS5 & Sanitary services/cleanliness of the neighbourhood & 28.38 & 25 \\
\hline SCF7 & Market/shopping facilities & 28.03 & 26 \\
\hline SIS3 & Garbage/waste collection/disposal systems & 24.37 & 27 \\
\hline SIS6 & Management and maintenance of facilities & 22.45 & 28 \\
\hline
\end{tabular}

Notes - (FDU: Features of Dwelling Units; SCF: Community Facilities; SNE: Social/Neighbourhood Environment; SIS: Infrastructural Services)

Source: Authors' Fieldwork, 2020

The negative contribution of the infrastructure services component to the habitability index was typical in a low-income rural community of a developing country. The high dissatisfaction with the infrastructure services in Salman was strongly influenced by the limited amenities for sanitary services, garbage disposal systems and poor management and maintenance of facilities by the local government agencies. This trend was observed in the assessment of residential satisfaction elsewhere in Ghana (Danquah et al., 2014) and Nigeria (Ibem \& Aduwo, 2013; Ilesanmi, 2010; Jiboye, 2009; Ogu, 2002) where inadequate provision and non-maintenance of infrastructure services by the local authorities prevailed. 


\section{Conclusion, Policy and Managerial Implications}

The study has applied and deliberated residential satisfaction as an approach for the assessment of MIDR, with Salman in Ghana as a case study. It offers an empirical indication of the main determinants of residential satisfaction in the MIDR. It is concluded from the findings of the study, that the relocated Salman community was satisfied with their residential environment, based on their satisfaction with three components, namely, dwelling units, community facilities and social/neighbourhood environment. The study identified infrastructural facilities as the critical component the community was highly dissatisfied with, in addition to the location of the market and shopping facilities. While the residents' high overall residential satisfaction was attributable to their involvement in all stages of the resettlement development, poor management and maintenance of facilities accounted for their dissatisfaction with infrastructure facilities.

The identification of the factors that influenced the residential satisfaction in this study reveals essential intuitions policy that makers can use to achieve residents' expectations in MIDR and to establish standards for public housing. For instance, the policy implication of the lowest satisfaction index recorded for the infrastructural services component is that residential satisfaction in rural resettlements can be enhanced through improved management and maintenance of public facilities. Therefore, there should always be specific policies for the transfer and expansion of infrastructure and maintenance responsibilities, in addition to enforcement of local government by-laws on sanitation and solid waste management within resettlements developed by private entities. Besides, since beneficiary participation has an increased tendency to improve residential satisfaction, project affected persons should always be consulted during the project layout planning, architectural design, specifications and construction of the buildings and public infrastructure.

Further studies are required to ascertain the extent and the types of modifications made to the existing prototype houses by house owners and the reasons for the alterations. The research is necessary to enhance the standardisation of buildings in resettlement housing schemes by making provisions in the design of the homes for future incremental extensions, remodelling and modifications to accommodate the varying needs of house owners.

\section{References}

Addo, I. A. (2016). 'Assessing residential satisfaction among low-income households in multi-habited dwellings in selected low-income communities in Accra'. Urban Studies, 53(4), pp. 631-650.

Adu-Aryee, V. (1993). 'Resettlement in Ghana: From Akasombo to Kpong'. In Adu-Aryee, \& M. A. Cernea (Ed.), Anthropological Approaches to Resettlement: Policy, Practice and Theory (pp. 133-152). Boulder: Westview Press.

Al-Eisa, A. S., \& Alhemoud, A. M. (2009). 'Using a multiple-attribute approach for measuring customer satisfaction with retail banking services in Kuwait'. International Journal of Bank Marketing, 27(4), pp. 294314.

Amerigo, M., \& Aragones, J. I. (1997). 'A theoretical and methodological approach to the study of residential satisfaction'. Journal of Environmental Psychology, 17(1), pp. 47-57.

Andersen, H. S. (2008). 'Why do residents want to leave deprived neighbourhoods? The importance of residents' subjective evaluations of their neighbourhood and its reputation'. Journal of Housing and the Built Environment, 23(2), pp. 79-101.

Askland, H. H. (2018). 'A dying village: mining and the experiential condition of displacement'. The Extractive Industries and Society, 5(2), pp. 230-236.

Asthana, R. (1996). 'Involuntary resettlement: a survey of international experience'. Economic and Political Weekly, pp. 1468-1475.

Baiden, P., Arku, G., Luginaah, I., \& Asiedu, A. B. (2011). 'An assessment of residents' housing satisfaction and coping in Accra, Ghana'. Journal of Public Health, 19(1), pp. 29-37. doi:10.1007/s10389-010-0348-4

Cernea, M. M. (2004). 'Impoverishment Risks, Risk Management, and Reconstruction: A Model of Population Displacement and Resettlement'. In UN Symposium on Hydropower and Sustainable Development (Vol.27). Washington, D.C., USA: George Washington University.

Cernea, M. M., \& McDowell, C. (Eds.). (2000). 'Risks and Reconstruction: Experiences of resettlers and refugees'. The World Bank.

Danquah, J. A., Attippoe, J. A., \& Ankrah, J. S. (2014). 'Assessment of Residential Satisfaction in the Resettlement Towns of The Keta Basin in Ghana'. International Journal Civil Engineering, Construction and Estate Management, 12(3), pp. 26-45.

De Wet, C. (2000). 'The experience with dams and resettlement in Africa'. Contributing Paper Prepared for Thematic Review I, 3. Cape Town, South Africa: World Commission on Dams.

Djebuarni, R., \&. Al-Abed, A. (2000). 'Satisfaction level with the neighbourhood in low-income housing in Yemen'. Property Management, 18(4), pp. 230-242.

Downing, T. E. (2002). 'Avoiding New Poverty: Mining-Induced Displacement and Resettlement' (Vol. 52). London: International Institute for Environment and Development. 
Fowler, Jr, F. J., \& Cosenza, C. (2009). 'Design and evaluation of survey questions'. The SAGE handbook of applied social research methods, 375-412.

Galster, G. C. (1987). 'Identifying the correlates of dwelling satisfaction: an empirical critique'. Environment and Behavior, 19(5), pp. 539-568.

Galster, G. C. (1985). 'Evaluating indicators for housing policy: Residential satisfaction vs marginal improvement priorities'. Social Indicators Research, 16(4), pp. 415-448.

Ha, S. (2008). 'Social housing estates and sustainable community development in South Korea'. Habitat International, 32(3), pp. 349-363.

Hashim, A. H. (2003). 'Residential satisfaction and social integration in public low-cost housing in Malaysia'. Pertanika Journal of Social Science and Humanity, 11(1), pp. 1-10.

Howard, J. A., \& Sheth, J. N. (1969). 'The theory of buyer behaviour'. New York: Jonh Wiley and Sons.

Hui, E. C. M., \& Yu, K. H. (2009). 'Residential mobility and ageing population and in Hong Kong'. Habitat International, 33(1), pp. 10-14.

Ibem, E. O., \& Aduwo, E. B. (2013). 'Assessment of residential satisfaction in public housing in Ogun State, Nigeria'. Habitat International, 40, pp. 163-175

Ibem, E. O., \& Amole, D. (2013). 'Residential satisfaction in public core housing in Abeokuta, Ogun State, Nigeria'. Social Indicators Research, 113(1), pp. 563-581.

Ilesanmi, A. O. (2010). 'Post-occupancy evaluation and residents' satisfaction with public housing in Lagos, Nigeria'. Journal of Building Appraisal, 6(2), pp. 153-169.

Jaafar, M., \& Hasan, N. L. (2005). 'The determinants of housing satisfaction level: A study on residential development project by Penang Development Corporation (PDC)'. Journal Kemanusiaan, 3(2).

Jiang, J. J., Klein, G., \& Saunders, C. (2012). 'Discrepancy theory models of satisfaction in IS research'. In Information systems theory (pp. 355-381). Springer, New York, NY

Jiboye, A. D. (2009). 'Evaluating tenants' satisfaction with public housing in Lagos, Nigeria'. Town Planning and Architecture, 33(4), pp. 239-247.

Jiboye, A. D. (2012). 'Post-occupancy evaluation of residential satisfaction in Lagos, Nigeria: Feedback for residential improvement'. Frontiers of Architectural Research, 1(3), pp. 236-243.

Klein, G., Jiang, J., \& Cheney, P. (2009) 'Resolving difference score issues in information systems research'. Management Information Systems Quarterly. 33(4), pp. 811-826.

Lane, S. \& Linsey, J. (1980). 'Housing tenure and housing satisfaction'. Journal of Consumer Affairs, 14(2), pp. 341-365. Retrieved March 21, 2018, from http://www.jstor.org/stable/23859397

LaTour, S. A., \& Peat, N. C. (1979). 'Conceptual and methodological issues in consumer satisfaction research'. ACR North American Advances.Li, S. M., \& Song, Y. L. (2009). Redevelopment, displacement, housing conditions, and residential satisfaction: a study of Shanghai. Environment and Planning A, 41(5), pp. 1090-1108.

Li, S. M., \& Song, Y. L. (2009). 'Redevelopment, displacement, housing conditions, and residential satisfaction: a study of Shanghai'. Environment and Planning A, 41(5), pp. 1090-1108.

Li, Z., \& Wu, F. (2013). 'Residential satisfaction in China's informal settlements: A case study of Beijing, Shanghai, and Guangzhou'. Urban Geography, 34(7), pp. 923-949.

Liu, A. M. (1999). 'Residential satisfaction in housing estates: a Hong Kong perspective.' Automation in construction, 8, pp. 511-524.

Lu, M. (1999). 'Determinants of residential satisfaction: ordered logit vs regression models'. Growth and Change, 30, pp. 264-287.

Mettle, M. (2011). Forced Resettlement in Ghana: The Dam and the Affected People - The Bui Hydroelectric Power Project in Ghana. Master's Thesis for Award of Master of Philosophy in Development Studies Specialising in Geography. (Norges teknisk-naturvitenskapelige universitet, Fakultet for samfunnsvitenskap og teknologiledelse, Geografisk institutt) Norwegian University of Science and Technology (NTNU), Trondheim, Norway.

Mkuzi, H., Mwaguni, S., \& Danda, K. (2013). 'Resettling Displaced people in a coastal Zone mining project: Evaluating the Agricultural and Land Potential of the Proposed Resettlement site-A Case of Titanium Mining in Kenya'. Journal of Environment and Earth Science, 3(4). ISSN 2224-3216 (Paper) ISSN. pp. 2225-0948.

Mohit, M. A., Ibrahim, M., \& Rashid, Y. R. (2010). 'Assessment of residential satisfaction in newly designed public low-cost housing in Kuala Lumpur, Malaysia'. Habitat International, 34, pp. 18-27.

Morris, E. W., \& Winter, M. (1975). 'A theory of family housing adjustment'. Journal of Marriage and the Family, 37, pp. 79-88.

Morris, E. W., \& Winter, M. (1978). Housing, family and society. New York: John Wiley and Sons.

Obour, P. B., Owusu, K., Agyeman, E. A., Ahenkan, A., \& Madrid, À. N. (2016). 'The impacts of dams on local livelihoods: a study of the Bui Hydroelectric Project in Ghana'. International Journal of Water Resources Development, 32(2), pp. 286-300. 
Ogu, V. I. (2002). 'Urban residential satisfaction and the planning implications in developing world context: the example of Benin City, Nigeria’. International Planning Studies, 7(1), pp. 37-53.

Olatubara, C. O., \& Fatoye, E. O. (2007). 'Evaluation of the satisfaction of occupants of the Abesan public lowcost housing estate in Lagos State, Nigeria'. The Nigerian Journal of Economic and Social Studies, 49(1), pp. 5-9.

Oliver, R. L. (1981). 'Measurement and evaluation of satisfaction processes in retail settings'. Journal of Retailing, $57(3)$, pp. 25-48.

Owen, J. R., \& Kemp, D. (2015). 'Mining-induced displacement and resettlement: a critical appraisal'. Journal of Cleaner Production, 87, pp. 478-488. doi:http://dx.doi.org/10.1016/j.jclepro.2014.09.087

Owen, J. R., \& Kemp, D. (2016). 'Can planning safeguard against mining and resettlement risks'? Journal of Cleaner Production, 133, pp. 1227-1234.

Parke. A., Kearns, A., \& Atkinson, R. (2002). 'What makes people dissatisfied with their neighbourhoods'? Urban Studies, 39(13), pp. 2413-2438.

Parker, C., \& Mathews, B. P. (2001). 'Customer satisfaction: contrasting academic and consumers' interpretations'. Marketing Intelligence \& Planning, 19(1), pp. 38-44.

Rohe, W. M., Van Zandt, S., \& McCarthy, G. (2013). 'The social benefits and costs of home-ownership: A critical assessment of the research'. The affordable housing reader, 40, pp. 00-01.

Salleh, A. (2008). 'Neighbourhood factors in private low-cost housing in Malaysia'. Habitat International, 32(4), pp. 485-494.

Savasdisara, T., Tips, W. E., \& Suwannodom, S. (1989). 'Residential satisfaction in private estates in Bangkok: A comparison of low-cost housing estates and determinant factors'. Habitat International, 13(1), pp. 65-73.

Schueler, V., Kuemmerle, T., \& Schröder, H. (2011). 'Impacts of surface gold mining on land use systems in Western Ghana'. Ambio, 40(5), pp. 528-539.

Scudder, T., \& Colson, E. (1982). From welfare to development: a conceptual framework for the analysis of dislocated people. In A. H. Oliver-Smith, Involuntary migration and resettlement; the problems and responses of dislocated people (pp. 267-287). Boulder, Colombia: Westview Press.

Shaw, J., \& Ahmed, I. ( 2010). Design and delivery of post-disaster housing resettlement programmes: Case studies from Sri Lanka and India. Melbourne: The Royal Melbourne Institute of Technology.

Sinai, I. (2001). 'Intraurban housing mobility in a traditional West African city: Shelter or business decision'? Urban Studies, 38(3), pp. 535-540.

Singh, A. S., \& Masuku, M. B. (2014). 'Sampling techniques \& determination of sample size in applied statistics research: An overview'. International Journal of Economics, Commerce and Management, 2(11), pp. 1-22.

Sonter, L. J., Barrett, D. J., Soares-Filho, B. S., \& Moran, C. J. (2014). 'Global demand for steel drives extensive land-use change in Brazil's Iron Quadrangle.' Global Environmental Change, 26, pp. 63-72.

Stanley, J. (2004). 'Development-induced displacement and resettlement'. Forced Migration Online Research Guide, Refugee Studies Centre, University of Oxford.

Theodori, G. (2001). 'Examining the effects of community satisfaction and attachment on individual well-being'. Rural Sociology, 66, pp. 618-628.

Ukoha, O. M., \& Beamish, J. O. (1997). 'Assessment of residents' satisfaction with public housing in Abuja, Nigeria'. Habitat International, 21(4), pp. 445-460.

Van der Ploeg, L., \& Vanclay, F. (2018). 'Challenges in implementing the corporate responsibility to respect human rights in the context of project-induced displacement and resettlement'. Resources Policy, 55, pp. 210222.

Yamane, T. (1967). Statistics: An Introductory Analysis (2nd ed.). New York: Harper. 